\title{
FACTORS AFFECTING SUPEROVULATION, FERTILIZATION AND RECOVERY OF SUPEROVULATED OVA IN PREPUBERAL CATTLE
}

\author{
HIDEO ONUMA,* J. HAHN $\dagger$ AND R. H. FOOTE \\ Department of Animal Science, Cornell University, \\ Ithaca, New York, U.S.A.
}

(Received 22nd November 1968, revised 3rd April 1969)

\begin{abstract}
Summary. Holstein calves, reared from birth under standard conditions, were given various combinations of PMSG-LH or PMSG-HCG at 8 to 9 weeks, or at 17 weeks of age. Follicular development was variable, but averaged fifty-three follicles $\geqslant 1.0 \mathrm{~cm}$ in diameter following administration of either 1500 or 2000 i.u. of PMSG. Ovulation rate was $79 \%$ following $50 \mathrm{mg}$ of $\mathrm{LH}$, but it was only $16 \%$ following $1500 \mathrm{i}$.u. of HCG. The presence of young corpora lutea or the administration of progesterone accelerated transport of ova into the uterus and was associated with a reduced percentage of cleaved ova and a lower recovery rate. Liquid semen was superior to frozen semen in initiating cleavage of ova. Under optimum conditions, approximately $75 \%$ of the developed follicles ovulated and a similar proportion of ova was cleaved at the time of collection or cleaved in culture. Recovery rate was usually less than $30 \%$.
\end{abstract}

\section{INTRODUCTION}

Since the early work on superovulation in sexually mature cattle by Casida, Meyer, McShan \& Wisnicky (1943), many techniques have been used (Dowling, 1949; Umbaugh, 1949; Rowson, 1951; Brock \& Rowson, 1952; Lamming \& Rowson, 1952; Willett, McShan \& Meyer, 1952; Dziuk, Donker, Nichols \& Petersen, 1958; Hafez, Sugie \& Gordon, 1963a). Among the more successful reports are those of Avery, Fahning \& Graham (1962), Avery \& Graham (1962), Hafez, Sugie \& Hunt (1963b) and Scanlon, Sreenan \& Gordon (1968).

Successful superovulation in sexually immature cattle would have an economic advantage as a source of ova for experimental study and genetic advantages from the standpoints of reducing the generation interval and facilitating progeny testing of females. However, the superovulatory response in calves has been variable (Avery et al., 1962; Jainudeen, Hafez \& Lineweaver, 1966), and fertilization rates have been low (Casida et al., 1943; Black, Ulberg, Christian \& Casida, 1953; Marden, 1953; Avery \& Graham, 1962; Howe,

* Present address: National Institute of Animal Industry, Chiba-shi, Japan.

$\dagger$ Present address: Tierärztliche Hochschule, Hanover, West Germany. 
Black, Foley \& Black, 1962; Jainudeen et al., 1966). The objective of the present study was to develop more dependable methods for superovulating calves, and for fertilizing and recovering ova.

\section{MATERIALS AND METHODS}

Holstein heifers were reared from birth under standard environmental conditions; forty were used experimentally at 8 to 9 weeks of age, fifteen at 17 weeks and one at 26 weeks of age.

\section{Superovulation}

Follicular development and ovulation were induced with pregnant mare serum gonadotrophin (PMSG: Equinex, Ayerst) given intramuscularly, followed 5 days later with an intravenous injection of luteinizing hormone $(\mathrm{LH})$. Sources of LH tested were Armour LH (LH), Armour experimental LH (LHE), bovine LH (NIH-LH-B5) and human chorionic gonadotrophin (HCG: Follutein, Squibb). Dosages used in Exp. 1 are shown in Table 1. In Exp. 2, progesterone and oestrogen treatments were included. The animals were injected intramuscularly with $50 \mathrm{mg}$ of progesterone 4 and 2 days before injection with $1500 \mathrm{i} . \mathrm{u}$. of PMSG, or with $10 \mathrm{mg}$ of $17 \beta$-oestradiol 4 days after the PMSG injection. Ovulation was induced with $50 \mathrm{mg}$ of $\mathrm{LH}$.

\section{Insemination}

Animals were too small to inseminate by the rectal fixation method. Speculum, forceps and surgical methods were used. In the first method, a vaginal speculum with a light and a stainless steel pipette were used. Semen could not usually be deposited beyond the cervical entrance. In the second method, the cervix was retracted toward the vulva with small cervical forceps manipulated through a duck-bill type vaginal speculum. This facilitated insemination into the uterus. The third technique involved insemination into the uterine horns through a flank incision using a blunt 20-gauge needle attached to a plastic insemination pipette.

Inseminations were done at the time $\mathrm{LH}$ was administered, and repeated 24 or $48 \mathrm{hr}$ later, except that the surgically-treated individuals were inseminated only on the day after $\mathrm{LH}$ injection. One $\mathrm{ml}$ of frozen semen containing 100 million motile spermatozoa, or liquid semen containing 10 million motile spermatozoa from bulls of high fertility was used for insemination.

\section{Measurement of ovarian response}

Ovaries were measured in surgically-treated animals and weights taken in animals which were killed. Unruptured follicles $\geqslant 1.0 \mathrm{~cm}$ in diameter plus the ovulation points and recently formed corpora lutea (CL) were combined to indicate the total number of developed follicles. Histological sections of the ovaries were prepared. 
Collection and culture of ova

Ova were recovered 3 days after the injection of $\mathbf{L H}$. In slaughtered animals, the oviducts, uterine horns and body of the uterus were each flushed twice with heated bovine serum (Chang, 1949) containing 100 units of penicillin and 0.5 $\mathrm{mg}$ of streptomycin per $\mathrm{ml}$. Ova were also collected from animals at laparotomy, as previously described (Onuma, Hahn, Maurer \& Foote, 1969).

Ova were examined microscopically for stage of development and morphological abnormalities. Viability was studied by culturing them in $0.2-\mathrm{ml}$ droplets of heated bovine serum under $10 \mathrm{ml}$ of paraffin oil (Onuma, Maurer \& Foote, 1968).

Data obtained were analysed by $\chi^{2}$ and analysis of variance. Significance levels are indicated in the text.

\section{RESULTS}

Dose of PMSG, LH and HCG

Follicular development, ovulation rate and efficiency of ovum recovery resulting from different levels and combinations of gonadotrophins in Exp. 1 are summarized in Table 1 . The percentage of ovulations increased as the dosage

TABLE 1

SUPEROVULATORY RESPONSE IN GALVES 8 AND 9 WEEKS OLD TREATED WITH PMSG FOLLOWED BY LH OR HCG

\begin{tabular}{|c|c|c|c|c|c|c|c|c|}
\hline \multicolumn{2}{|c|}{ Ovulatory injection } & \multicolumn{2}{|c|}{ No. of calves } & \multirow{3}{*}{$\begin{array}{l}\text { Ave. no. of } \\
\text { developed } \\
\text { follicles } \\
\geqslant 1.0 \mathrm{~cm}\end{array}$} & \multirow{2}{*}{\multicolumn{2}{|c|}{ Ovulation }} & \multirow{2}{*}{\multicolumn{2}{|c|}{ Recovered ova }} \\
\hline \multirow[b]{2}{*}{ Hormone } & \multirow{2}{*}{$\begin{array}{l}\text { Dose } \\
(\mathrm{mg})\end{array}$} & \multirow{2}{*}{$\begin{array}{l}\text { Fraction } \\
\text { ovulated }\end{array}$} & \multirow{2}{*}{$\begin{array}{l}\text { Recovered } \\
\text { ova }\end{array}$} & & & & & \\
\hline & & & & & Mean & $\%$ & Mean & $\%$ \\
\hline LHE $\dagger$ & $\begin{array}{c}25 \\
75 \text { to } 150\end{array}$ & $\begin{array}{c}2 / 2 \\
10 / 10\end{array}$ & $\begin{array}{l}2 \\
9\end{array}$ & $\begin{array}{l}30 \\
62\end{array}$ & $\stackrel{2}{40^{*}}$ & $\begin{array}{c}7 \\
66^{* *}\end{array}$ & $\begin{array}{l}2 \\
7\end{array}$ & $\begin{array}{l}75 \\
16^{* *}\end{array}$ \\
\hline LH & $\begin{array}{l}25 \\
50\end{array}$ & $\begin{array}{l}3 / 5 \\
4 / 4\end{array}$ & $\begin{array}{l}2 \\
4\end{array}$ & $\begin{array}{l}38 \\
48\end{array}$ & $\begin{array}{l}10 \\
38^{*}\end{array}$ & $\begin{array}{l}28 \\
79 * *\end{array}$ & $11^{* *}$ & $\begin{array}{c}8 \\
32^{*}\end{array}$ \\
\hline NIH-LH $\ddagger$ & 10 to 20 & $4 / 4$ & 3 & 70 & 24 & 35 & 3 & 11 \\
\hline HCG & $1500 \$$ & $4 / 4$ & 3 & 50 & 8 & 16 & 2 & 29 \\
\hline \multicolumn{2}{|c|}{ Total or mean } & $27 / 29$ & 23 & 53 & 25 & 47 & 5 & 19 \\
\hline
\end{tabular}

* $P<0.05, * * P<0.01$ for comparisons within groups.

† One-third the potency of the commercial Armour LH.

NIH-LH-B5 assayed 0.87 units/mg.

f HCG dose in i.u.

of $\mathrm{LH}$ within groups increased. Differences in ovulation rate among groups were also significant $(P<0 \cdot 01)$. Results presented in Table 1 have been averaged over two levels of PMSG used (1500 and 2000 i.u.) because follicular response did not differ significantly $(P>0.05)$. Recovery of ova was $36 \%$ following the lower dose of PMSG as compared with $13 \%$ following 2000 i.u. PMSG $(P<0.05)$.

Fourteen of the twenty-nine calves had one or two cL each, which were judged from their size, colour and histological appearance to be several days old. These are believed to have originated from follicles which had undergone ovulation by treatment with PMSG. 
Supplemental progesterone and oestradiol

The results of Exp. 2 are shown in Table 2. Although progesterone and oestradiol appeared to suppress follicular development, the only statistically significant depression was in the percentage of ovulations. None of the oestrogentreated animals had premature ovulations. Progesterone appeared to speed ovum transport, as the proportion of ova recovered from the oviducts was 76.9 , 8.3 and $77.8 \%$ for the control, progesterone and oestradiol groups, respectively.

TABLE 2

EFFECT OF PROGESTERONE AND OESTRADIOL ON SUPEROVULATION

\begin{tabular}{|c|c|c|c|c|c|c|c|c|}
\hline \multirow[b]{2}{*}{ Group } & \multirow{2}{*}{$\begin{array}{c}\text { Wt } \\
\text { of both } \\
\text { ovaries } \\
(\mathrm{g})\end{array}$} & \multirow{2}{*}{$\begin{array}{l}\text { No. of } \\
\text { developed } \\
\text { follicles } \\
\geqslant 1.0 \mathrm{~cm}\end{array}$} & \multicolumn{2}{|c|}{ Ovulations } & \multicolumn{2}{|c|}{ Recovered ova } & \multicolumn{2}{|c|}{ Cleaved ova } \\
\hline & & & $\begin{array}{c}\text { Mean } \\
\text { no. }\end{array}$ & $\%$ & $\begin{array}{c}\text { Mean } \\
\text { no. }\end{array}$ & $\%$ & $\begin{array}{c}\text { Mean } \\
\text { no. }\end{array}$ & $\%$ \\
\hline $\begin{array}{l}\text { Control } \\
\text { Progesterone } \\
\text { Oestradiol }\end{array}$ & $\begin{array}{r}116 \cdot 0 \\
85 \cdot 7 \\
76 \cdot 6\end{array}$ & $\begin{array}{l}76 \\
46 \\
50\end{array}$ & $\begin{array}{l}56 \\
24 \\
24\end{array}$ & $\begin{array}{l}73 \\
51^{* *} \\
47^{* *}\end{array}$ & $\begin{array}{l}6 \\
3 \\
7\end{array}$ & $\begin{array}{l}12 \\
13 \\
28 * *\end{array}$ & $\begin{array}{l}3 \dagger \\
1 \\
4\end{array}$ & $\begin{array}{l}35 \dagger \\
17 \\
56^{*}\end{array}$ \\
\hline
\end{tabular}

The percentage figures are averages of the percentages for each calf. There were four calves per group. $* P<0.05 ; * * P<0.01$.

$\dagger$ Based on three calves because one of the four calves was not inseminated.

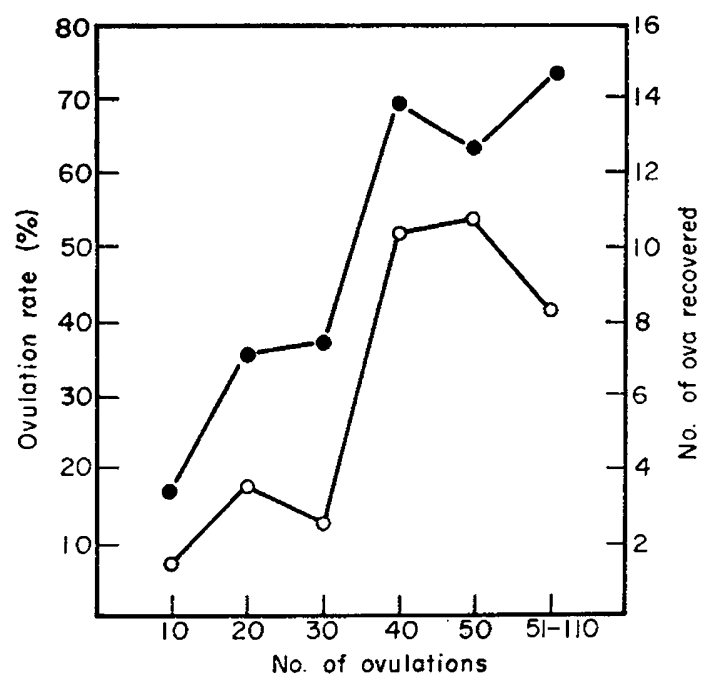

TExT-FIG. 1. Relationship between ovulation rate and rate of ovum recovery. Ovulation rate in $\%$, number of ova recovered 0 .

\section{Recovery of ova}

Recovered ova ranged from one to sixteen cells. Most cleaved ova contained four to eight blastomeres. Recovery rates were usually higher when ova were flushed in vitro, averaging $19 \%$ for the latter versus $11 \%$ for in vivo flushing $(P<0 \cdot 05)$. This may have resulted, in part, from the difficulty of completely flushing the uterus through the abdominal incision.

Text-figure 1 shows that the percentage and number of ovulations increased 
together and were highly correlated with the number of ova recovered $(P<0.01)$. The overall average number of recovered ova was $5 \cdot 3$, accounting for $18 \cdot 1 \%$ of the ovulations. Ovulation appeared to be more highly synchronized in the animals from which a high proportion of ova were collected.

\section{Distribution of ova}

When a developed cL was present, fewer calves had ova in the oviducts and there were fewer ova in the oviducts (Table 3 ). This suggests that progesterone may have hastened transport of the ova.

TABLE 3

RELATIONSHIP OF THE PRESENCE OF A CL TO DISTRIBUTION OF OVA IN THE GENITAL TRAGT

\begin{tabular}{c|c|c|c|c}
\hline \multirow{3}{*}{$\begin{array}{c}\text { Condition } \\
\text { of } \\
\text { ovaries }\end{array}$} & \multicolumn{4}{|c}{ Distribution of recovered ova } \\
\cline { 2 - 5 } No cL & $\begin{array}{c}\text { Location } \\
\text { of ova }\end{array}$ & $\begin{array}{c}\text { No. of calves } \\
\text { represented }\end{array}$ & $\begin{array}{c}\text { Total } \\
\text { ova }\end{array}$ & $\begin{array}{c}\% \text { of } \\
\text { ova }\end{array}$ \\
\hline \multirow{2}{*}{ cL $\dagger$} & $\begin{array}{c}\text { Oviducts } \\
\text { Ov.+Ut. }\end{array}$ & 9 & 90 & 76 \\
& Uterus & 3 & $-\overline{3}$ & 24 \\
\hline & Oviducts & $3^{*}$ & 44 & $50^{* *}$ \\
& $\begin{array}{c}\text { Ov.+Ut. } \\
\text { Uterus }\end{array}$ & 10 & $-\overrightarrow{4}$ & 50 \\
\hline
\end{tabular}

* $P<0.05 ; * * P<0.01$ compared to animals with no $\mathrm{cL}$. $f$ cr. present at the time of LH injection.

\section{Fertilization of ova}

In nineteen calves inseminated with frozen semen, only $6 \%$ of ninety-six ova recovered were cleaved. However, most of these calves were inseminated by the speculum method into the cervix. In $43 \%$ of the animals, a few spermatozoa were found in the uterine flushings, indicating that some spermatozoa were transported through the cervix. When nineteen calves were inseminated with the forceps method and spermatozoa were deposited into the uterus, spermatozoa were found in the uteri of all calves at slaughter and in the oviducts of about one-third of them. Of 110 ova recovered, $43 \%$ had cleaved. However, liquid semen was used with the forceps method, so from these observations it was not possible to ascertain the relative effects of site of deposition and kind of semen on fertility.

The results of an experiment designed to test directly (1) the efficacy of frozen semen versus liquid semen deposited into the uterus, and (2) the relationship between the number of inseminations and the proportion of cleaved ova are shown in Table 4. As an additional indication of fertilization in these animals, the one-celled ova which showed equal cleavage during culture were tabulated. When the percentage of ova which were cleaved at the time of collection was combined with that of the one-celled ova which cleaved in culture, there was a highly significant difference between frozen and liquid semen $(P<0.01)$. 
Also, three inseminations gave a significant improvement over two inseminations in the percentage of ova cleaved at the time of ovum collection $(P<0.05)$.

TABLE 4

EFFEGTS OF KIND OF SEMEN AND FREQUENGY OF INTRA-UTERINE INSEMINATION ON FERTILIZATION OF SUPEROVULATED OVA IN GALVES 17 WEEKS OLD

\begin{tabular}{|c|c|c|c|c|c|c|c|}
\hline \multirow[b]{2}{*}{$\begin{array}{l}\text { Kind } \\
\text { of } \\
\text { semen }\end{array}$} & \multirow[b]{2}{*}{$\begin{array}{l}\text { No. of } \\
\text { insem. }\end{array}$} & \multicolumn{2}{|c|}{ Calves } & \multirow[b]{2}{*}{$\begin{array}{l}\text { Total ova } \\
\text { collected }\end{array}$} & \multicolumn{3}{|c|}{$\%$ cleaved ova } \\
\hline & & No. & $\begin{array}{l}\text { \% yielding } \\
\text { cleaved ova }\end{array}$ & & $\begin{array}{l}\text { When } \\
\text { collected }\end{array}$ & $\begin{array}{l}\text { Additional } \\
\text { cleavage } \\
\text { in culture } \ddagger\end{array}$ & Total \\
\hline Frozen & $\begin{array}{l}2 \times \\
3 \times \\
\text { Total }\end{array}$ & $\begin{array}{l}3 \\
4 \\
7\end{array}$ & $\begin{array}{r}100 \\
50 \\
71\end{array}$ & $\begin{array}{l}13 \dagger \\
20 \\
33\end{array}$ & $\begin{array}{l}15 \\
10 \\
12\end{array}$ & $\begin{array}{l}15 \\
25 \\
21\end{array}$ & $\begin{array}{l}31 \\
35 \\
33\end{array}$ \\
\hline Liquid & $\begin{array}{c}2 \times \\
3 \times \\
\text { Total }\end{array}$ & $\begin{array}{l}4 \\
4 \\
8\end{array}$ & $\begin{array}{l}100 \\
100 \\
100\end{array}$ & $\begin{array}{l}25 \\
43 \\
68\end{array}$ & $\begin{array}{c}0 \\
56 \\
35^{*}\end{array}$ & $\begin{array}{l}56 \\
26 \\
37\end{array}$ & $\begin{array}{l}56 \\
81 \\
72^{* *}\end{array}$ \\
\hline \multicolumn{2}{|c|}{ Grand total } & 15 & 86 & 101 & 28 & 32 & 59 \\
\hline
\end{tabular}

$* P<0.05 ; * * P<0.01$ compared with frozen semen.

$\dagger$ Three one-cell ova were lost in handling.

$¥$ Cultured in heated bovine semen for $48 \mathrm{hr}$.

\section{DISCUSSION}

The average follicular response to 1500 to 2000 i.u. of PMSG was high in twentynine calves 8 to 9 weeks of age (Table 1), but individual response was variable. The number of follicles $\geqslant 1.0 \mathrm{~cm}$ in diameter ranged in individual calves from 2 to 154 . Similar variability has been reported previously in calves (Avery et al., 1962; Howe et al., 1962; Jainudeen et al., 1966), and in cows (Hammond \& Bhattacharya, 1944; Umbaugh, 1949; Rowson, 1951; Brock \& Rowson, 1952; Dziuk et al., 1958; Hafez et al., 1963a, b; Scanlon et al., 1968). Since calves in the present experiment were reared from birth under standard conditions, these data suggest that factors other than nutrition and management were important sources of variation.

The overall mean number of ovulations was twenty-five, indicating that calves are a good potential source of ova. The rate of about thirty to fifty ovulations per calf following injection of adequate doses of various LH preparations compares favourably with the results obtained by Jainudeen et al. (1966) with PMSG-LH combinations. It is superior to FSH-LH combinations (Onuma et al. 1969), excepting when considerably higher levels of LH were employed (Avery et al., 1962). Also, it is superior to the PMSG-HGG regimen, as reported by Jainudeen et al. (1966).

The recovery rate of ova was low. Part of this probably resulted from poor pick up of ova from the large superovulated ovaries by the small fimbriated end of the oviduct. The efficiency of recovery was improved somewhat by flushing in vitro, since ova in the uteri of calves could not be flushed as readily at laparotomy. 
Control of premature ovulation (ovulation probably resulting from the PMSG injection) appears to be important, not only to permit synchronized insemination and higher fertility (Table 2), but also to eliminate the effect of progesterone on rapid transport of ova (Table 3). The presence of a CL or the injection of progesterone caused a majority of the ova to be transported into the uterus within 3 days after administration of LH. Rowson (1951) reported a similar phenomenon in mature cows treated with PMSG in the presence of an active cL. The four animals given $17 \beta$-oestradiol 4 days after PMSG treatment did not ovulate prematurely. However, some older GL in other animals appeared to have originated from ovulations shortly after PMSG treatment. Oestradiol, on the day given, would not have blocked these ovulations. Oestradiol did not increase the number of developed follicles, as has been reported for mature cows (Hafez et al., 1963a).

Various methods of semen deposition in calves have yielded low fertilization rates. The highest cleavage rates were obtained by Avery \& Graham (1962) in calves old enough for rectal palpation to be used to assist in depositing the semen through the cervix. Limited observations on the distribution of spermatozoa in the reproductive tract and fertilization of ova in the present study suggest that semen deposition into the uterus is important, although spermatozoa can be transported from the vagina in young calves (Howe \& Black, 1963). Liquid semen yielded higher fertilization rates than frozen semen (Table 4). Frozen spermatozoa may not have survived as long in the female tract. Salamon \& Lightfoot (1967) found that initial fertilization with frozen ram spermatozoa was improved by intra-uterine insemination, but embryo mortality was high.

Time of ovulation was variable as judged from the cleaved ova obtained, which varied in development from two to sixteen blastomeres. This variability probably accounts for the slight improvement in cleavage rate resulting from three inseminations. Better synchronization is desirable. Nevertheless, when liquid semen was deposited in the uterus of calves two or three times, the proportion of cleaved ova was comparable to results reported for mature cows (Dowling, 1949; Willett et al., 1952; Avery \& Graham, 1962; Hafez et al., 1963a, b; Scanlon et al., 1968). Consequently, it appears that young calves may be used as suitable donors of cleaved ova for a variety of studies, particularly if recovery rates can be improved.

\section{ACKNOWLEDGMENTS}

This study was supported in part by Public Health Service Grant HD 03471 from The National Institute of Child Health and Human Development. Thanks are due to The Endocrine Study Section for the bovine LH, Eastern Artificial Insemination Cooperative, Inc., for semen and B. W. Hakes for technical assistance.

\section{REFERENCES}

Avery, T. L., Fahning, M. L. \& Graham, E. F. (1962) Investigations associated with the transplantation of bovine ova. II. Superovulation. F. Reprod. Fert. 3, 212.

AVERY, T. L. \& Graham, E. F. (1962) Investigations associated with the transplantation of bovine ova. III. Recovery and fertilization. 7. Reprod. Fert. 3, 218. 
Black, W. G., Ulberg, L. C., Christian, R. E. \& Casma, L. E. (1953) Ovulation and fertilization in the hormone-stimulated calf. 7. Dairy Sci. 36, 274.

Brock, H. \& Rowson, L. E. (1952) The production of viable bovine ova. J. agric. Sci., Camb. 42, 479.

Casida, L. E., Meyer, R. K., McShan, W. H. \& Wisnicky, W. (1943) Effects of pituitary gonadotropins on the ovaries and the induction of superfecundity in cattle. Am. J. vet. Res. 4, 76.

Chang, M. C. (1949) Effects of heterologous sera on fertilized rabbit ova. F. gen. Physiol. 32, 291.

Dowling, D. F. (1949) Problems of the transplantation of fertilized ova. F. agric. Sci., Camb. 39, 374.

Dziuk, P. J., Donker, J. D., Nichols, J. R. \& Petersen, W. E. (1958) Problems associated with the transfer of ova between cattle. Bull. Minn. agric. Exp. Stn, 222.

Hafez, E. S. E., Sugie, T. \& Gordon, I. (1963a) Superovulation and related phenomena in the beef cow. I. Superovulatory responses following PMS and HCG injections. F. Reprod. Fert. 5, 359.

HAFEz, E. S. E., Sugre, T. \& HunT, W. L. (1963b) Superovulation and related phenomena in the beef cow. II. Effect of oestrogen administration on production of ova. 7. Reprod. Fert. 5, 381.

Hammond, J., Jr \& Bhattacharya, P. (1944) Control of ovulation in the cow. F. agric. Sci., Camb. 34, 1.

HowE, G. R. \& BLACK, D. L. (1963) Spermatozoan transport and leucocytic responses in the reproductive tract of calves. 7. Reprod. Fert. 6, 305.

Howe, G. R., BlACK, D. L., Foley, R. G. \& BlACK, W. G. (1962) Ovarian activity in prepuberal dairy calves. F. Anim. Sci. 21, 82.

Jainudeen, M. R., Hafez, E. S. E. \& Lineweaver, J. A. (1966) Superovulation in the calf. F. Reprod. Fert. 12, 149.

Lamming, G. E. \& Rowson, L. E. A. (1952) Superovulation and ovum transplantation in cattle. Proc. 2nd Int. Cong. Physiol. Path. Anim. Reprod. Artif. Insem. 1, 144.

Marden, W. G. R. (1953) The hormone control of ovulation in the calf. F. agric. Sci., Camb. 43, 381.

Onuma, H., Hahn, J., Maurer, R. R. \& Foote, R. H. (1969) Repeated superovulation in calves. 7. Anim. Sci. 28, 634.

Onuma, H., Maurer, R. R. \& Foote, R. H. (1968) In vitro culture of rabbit ova from early cleavage stage to the blastocyst stage. F. Reprod. Fert. 16, 491.

Rowson, L. E. (1951) Methods of inducing multiple ovulation in cattle. F. Endocr. 7, 260.

Salamon, S. \& Lightroot, R. J. (1967) Fertilization and embryonic loss in sheep after insemination with deep frozen semen. Nature, Lond. 216, 194.

Scanlon, P., Sreenan, J. \& Gordon, I. (1968) Hormonal induction of superovulation in cattle. $\mathcal{J}$. agric. Sci., Camb. 70, 179.

UMBaUgh, R. E. (1949) Superovulation and ovum transfer in cattle. Am. F. vet. Res. 10, 295.

Willett, E. L., McShan, W. H. \& Meyer, R. K. (1952) Relation of stage of cycle and source of luteinizing hormone to superovulation in dairy cattle. Proc. Soc. exp. Biol. Med. 79, 396. 